\title{
Up-conversion luminescence of $\mathrm{GdVO}_{4}: \mathrm{Nd}^{3+} / \mathrm{Er}^{3+}$ and $\mathrm{GdVO}_{4}: \mathrm{Nd}^{3+} / \mathrm{Ho}^{3+} \mathrm{T}$
}

\section{phosphors under $808 \mathrm{~nm}$ excitation}

\author{
Dragana J. Jovanović ${ }^{a, *}$, Tamara V. Gavrilovića,b, Slobodan D. Dolića ${ }^{a}$, \\ Milena Marinović-Cincović ${ }^{\mathrm{a}}$, Krisjanis Smits ${ }^{\mathrm{b}}$, Miroslav D. Dramićanin ${ }^{\mathrm{a}}$ \\ ${ }^{a}$ Vinča Institute of Nuclear Sciences, University of Belgrade, P.O. Box 522, 11001 Belgrade, Serbia \\ ${ }^{\mathrm{b}}$ Institute of Solid State Physics, University of Lat via, 8 Kengaraga Street, Riga, LV 1063, Latvia
}

\section{ARTICLE INFO}

\section{Keywords:}

Up-conversion

Gadolinium vanadate

$\mathrm{GdVO}_{4}: \mathrm{Er}^{3+} / \mathrm{Nd}^{3+}$

GdVO $4: \mathrm{Ho}^{3+} / \mathrm{Nd}^{3+}$

808-nm excitation

\begin{abstract}
In recent years, there exists a tendency in research of up-conversion materials to shift excitation from $980 \mathrm{~nm}$ to shorter wavelengths. Here, in order to produce up-conversion luminescence emission of $\mathrm{GdVO}_{4}$-based materials under $808 \mathrm{~nm}$ excitation, polycrystalline powders of $\mathrm{GdVO}_{4}: \mathrm{Er}^{3+} / \mathrm{Nd}^{3+}$ and $\mathrm{GdVO}_{4}: \mathrm{Ho}^{3+} / \mathrm{Nd}^{3+}$ were suc-cessfully prepared by a hightemperature solid-state reaction technique. The prepared powders were highly crystalline with a single-phase zircon-type $\mathrm{GdVO}_{4}$ structure and consisted of micrometer-sized irregular spherical particles (2-6 $\mu \mathrm{m}$ in diameter). In all studied samples, visible up-conversion luminescence was successfully achieved under $808 \mathrm{~nm}$ illumination. Near-infrared pumping produced emission bands in the green, yellow-orange and green regions of the visible spectrum. The bands in the green and red regions of $\mathrm{GdVO}_{4}: \mathrm{Er}^{3+} / \mathrm{Nd}^{3+}$ as well as $\mathrm{GdVO}_{4}: \mathrm{Ho}^{3+} / \mathrm{Nd}^{3+}$ were, respectively, characteristic of $\mathrm{Er}^{3+}$ and $\mathrm{Ho}^{3+}$ ions. The dominant band originating from the ${ }^{4} \mathrm{G}_{7 / 2} \rightarrow{ }^{4} \mathrm{I}_{11 / 2}$ transition in $\mathrm{Nd}^{3+}$ ions was observed around $597 \mathrm{~nm}$ in all samples.
\end{abstract}

\section{Introduction}

Up-conversion (UC) luminescence is a unique anti-Stokes process where low-energy excitation light, usually near-infrared (NIR) light, is converted to higher-energy (NIR or visible/ultraviolet (Vis/UV)) light through sequential absorption of multiple photons or energy transfers. In recent years, upconverting materials, lanthanide-doped inorganic materials emitting NIR-toNIR or NIR-to-Vis/UV UC luminescence caused by NIR light illumination, have received much attention. Typically, these phosphors are made of low phonon energy host ma-terials which are double-doped with sensitizer ions (usually $\mathrm{Yb}^{3+}$ ) and activator ions $\left(\mathrm{Er}^{3+}, \mathrm{Tm}^{3+}\right.$, or $\mathrm{Ho}^{3+}$ in most cases). With the advent of nanotechnology and the inexpensive high-power infrared diode lasers, UC nanoparticles (UCNPs) have found many uses including, but not limited to, solar energy conversion, sensing and, in particular, a variety of biomedical applications [1-3].

Compared with conventional (down-conversion) phosphors excited by UV/Vis light, UCNPs used in biomedicine exhibit numerous ad-vantages, such as lower autofluorescence background, excellent pho-tostability, negligible photoblinking, less scattering and absorption, and deeper penetration into biological samples. Ytterbium $\left(\mathrm{Yb}^{3+}\right)$-sensi-tized UCNPs have been commonly used, and a $980 \mathrm{~nm}$ excitation is required to trigger the $\mathrm{UC}$ process; $\mathrm{Yb}^{3+}$ ions have a very narrow absorption band at about that wavelength and they can efficiently transfer excitation energy to $\mathrm{Er}^{3+}, \mathrm{Ho}^{3+}$ or $\mathrm{Tm}^{3+}$ ions. However, using an excitation source of $980 \mathrm{~nm}$ in biomedical applications has an in-trinsic disadvantage: water, as a principle constituent of biological materials, exhibits a strong absorption in the 900-1000 nm spectral region. The absorption attenuates excitation light passing through tis-sues which results in a shorter penetration, while absorbed light con-verted into heat induces local heating and may lead to overheating of cells or tissues in conjunction with substantial cell and tissue damage [1-6].

Shifting the excitation to shorter wavelengths, in particular, making use of $808 \mathrm{~nm}$ excitation, may both overcome the overheating issues and improve the penetration depth. At this wavelength, water absorp-tion is much lower (the absorption coefficient is $0.02 \mathrm{~cm}^{-1}$ at $808 \mathrm{~nm}$, in contrast to $0.48 \mathrm{~cm}^{-1}$ at $980 \mathrm{~nm}$ ), light penetrates deeper into tissues and tissues heat up slower [5]. In order to shift the excitation to shorter wavelengths, first, the $\mathrm{Yb}^{3+}$ ions have been replaced by suitable NIR organic sensitizers. However, unlike UCNPs, organic dyes are suscep-tible to photobleaching, thus making these NIR dyesensitized UCNPs unsuitable for a long-term usage. Recently, novel materials capable of producing UC luminescence under NIR excitation at $808 \mathrm{~nm}$ have come to prominence. $\mathrm{Yb}^{3+}$ ions and dyes have been superseded by ions of neodymium $\left(\mathrm{Nd}^{3+}\right)$ ions, as sensitizers into a typical sensitizer/ 

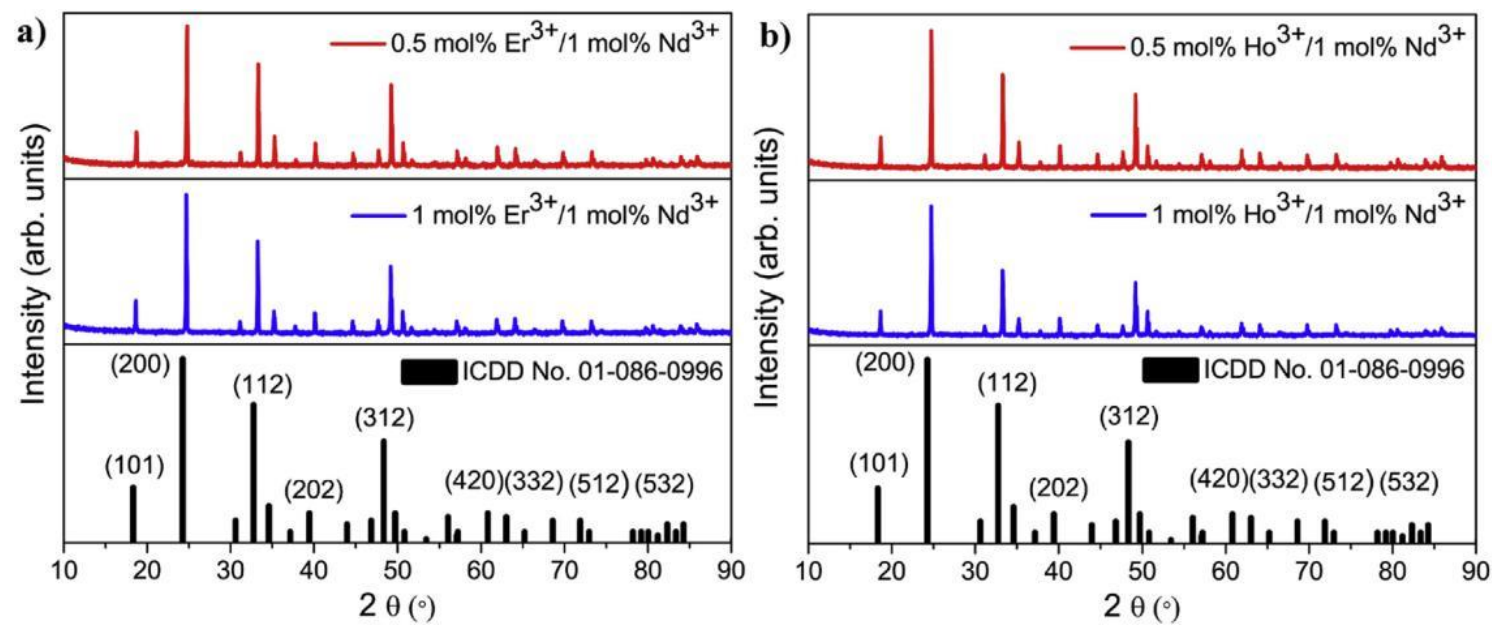

Fig. 1. XRD patterns of: a) $\mathrm{Er}^{3+} / \mathrm{Nd}^{3+}$ - and b) $\mathrm{Ho}^{3+} / \mathrm{Nd}^{3+}$-doped $\mathrm{GdVO}_{4}$ samples. Vertical bars denote the standard data for tetragonal zircon-type phase of bulk GdVO 4 (ICDD card No. 01-086-0996).

activator UC system, assume the role of $\mathrm{Yb}^{3+}$ ions as the main NIR absorber [4-6].

Gadolinium orthovanadate $\left(\mathrm{GdVO}_{4}\right)$ is a well-established host ma-trix used in preparation of various optical materials. These materials are utilized in many applications, such as solid-state laser hosts, polarizers, phosphors, cathode ray tubes, dye-sensitized solar cells, photovoltaic cells, laser diode pumped micro-lasers, and bio-probes [7-10]. Good down-conversion performance of lanthanide-doped $\mathrm{GdVO}_{4}$ could be attributed to the strong UV absorption of the $\mathrm{VO}_{4}{ }^{3-}$ groups and effi-cient energy transfer from the matrix to activator ions. $\mathrm{GdVO}_{4}$ also seems to be a promising host for phosphors which can be excited by NIR radiation because its high chemical stability, close lattice matches to dopant ions and comparatively low phonon energy. There are a dozen or so studies concerning successful preparation of $\mathrm{Yb}^{3+}$. sensitized

GdVO4-based materials, mostly double-doped and nanostructured: GdVO4: $\mathrm{Yb}^{3+} / \mathrm{Er}^{3+}[7,8,11-19], G d V O_{4}: \mathrm{Yb}^{3+} / \mathrm{Ho}^{3+}[8,12,16,18,19]$ and $\mathrm{GdVO}_{4}: \mathrm{Yb}^{3+} / \mathrm{Tm}^{3+}[8,12,16,18-20]$. Nothing about double-doped $\mathrm{GdVO}_{4}$ excited at $808 \mathrm{~nm}$, particularly about $\mathrm{Nd}^{3+}$-sensitized $\mathrm{GdVO}_{4}$-based materials, has been reported before.

Herein, in order to further our earlier work on up-converting lan-thanidedoped $\mathrm{GdVO}_{4}$ phosphors [7,8,10,15], $\quad \mathrm{GdVO}_{4}: \mathrm{Nd}^{3+} / \mathrm{Er}^{3+}$ and $\mathrm{GdVO}_{4}: \mathrm{Nd}^{3+} / \mathrm{Ho}^{3+}$ systems were synthesized using a high temperature solidstate reaction technique. The main aim was to produce UC lumi-nescence emission of these materials under $808 \mathrm{~nm}$ excitation.

\section{Experimental}

\subsection{Materials and methods}

Four $\mathrm{GdVO}_{4}$-based samples, $\mathrm{GdVO}_{4}: \mathrm{xmol} \mathrm{Ho}^{3+} / 1 \mathrm{~mol}^{2} \mathrm{Nd}^{3+}$ and GdVO4: $\mathrm{xmol} \% \mathrm{Er}^{3+} / 1 \mathrm{~mol} \% \mathrm{Nd}^{3+}(\mathrm{x}=0.5$ and 1$)$, were synthesized by hightemperature solid-state techniques. All chemicals: gadolinium (III) oxide, $\mathrm{Gd}_{2} \mathrm{O}_{3}$ (99.99\%, Alfa Aesar), holmium (III) oxide, $\mathrm{Ho}_{2} \mathrm{O}_{3}$ (99.99\%, Alfa Aesar), erbium (III) oxide, $\mathrm{Er}_{2} \mathrm{O}_{3}$ (99.99\%, Alfa Aesar), neodymium (III) oxide, $\mathrm{Nd}_{2} \mathrm{O}_{3}\left(99.99 \%\right.$, Alfa Aesar), ammonium va-nadate, $\mathrm{NH}_{4} \mathrm{VO}_{3}$ (Alfa Aesar, $99.999 \%$ ), sodium hydroxide and me-thanol were of the highest purity commercially available and were used without further purification.

In a typical synthesis, the starting materials $\mathrm{Gd}_{2} \mathrm{O}_{3}, \mathrm{Er}_{2} \mathrm{O}_{3}$ or $\mathrm{Ho}_{2} \mathrm{O}_{3}$, $\mathrm{Nd}_{2} \mathrm{O}_{3}$ and $\mathrm{NH}_{4} \mathrm{VO}_{3}$ in appropriate stoichiometric ratio were homogeneously mixed by dry grinding and then heated in open crucibles at three different temperature. First, a grounded mixture of precursors was heated from room temperature up to temperature of $800{ }^{\circ} \mathrm{C}$ and kept at this temperature for $1 \mathrm{~h}$. Next, the product was removed from the fur-nace, cooled down to room temperature, ground and, in order to complete the reaction, once reheated at $1100{ }^{\circ} \mathrm{C}$ for another $3 \mathrm{~h}$. After that, the resulting powder was ground homogeneously, and three times washed and centrifuged using $2 \mathrm{M} \mathrm{NaOH}$, water and methanol, re-spectively. At the end, the reaction product was additionally calcined at $1150{ }^{\circ} \mathrm{C}$ for $90 \mathrm{~min}$ to improve crystallinity and remove ligands at-tached to the particle surfaces during washing.

Additionally, GdVO $4: 12 \mathrm{~mol} \% \mathrm{Nd}^{3+}$ sample was prepared in the same manner as above, its phase purity were confirmed by XRD analysis and this sample was used in analysis of diffuse reflection spectra (see Section 3.2.1).

\subsection{Instruments}

Powder X-ray diffraction (XRD) measurements were performed on a Rigaku SmartLab diffractometer using $\mathrm{Cu}-\mathrm{K} \alpha 1,2$ radiation $(\lambda=0.15405 \mathrm{~nm})$. Diffraction data were recorded with a step size of $0.01^{\circ}$ and a counting time of $1 \mathrm{deg} / \mathrm{min}$ over the $2 \theta$ range of $10^{\circ}-90^{\circ}$. Microstructural characterization was performed on a JEOL JSM-6610LV scanning electron microscope (SEM).

Diffuse reflection spectra measurements were recorded with $1 \mathrm{~nm}$ resolution on a Shimadzu UV-Visible UV-2600 (Shimadzu Corporation, Japan) spectrophotometer equipped with an integrated sphere (ISR-2600 Plus (for UV-2600)) in the range from $230 \mathrm{~nm}$ to $1350 \mathrm{~nm}$. Luminescence measurements were performed using a Andor Shamrock B-303i spectrograph coupled with a CCD camera (Andor DU-401A-BV) at exit port (Input side slit width: $100 \mu \mathrm{m}$, spectral range: $500-715 \mathrm{~nm}$ ). The excitation source was $808 \mathrm{~nm}$ Multimode Laser Diode from Thorlabs operating at $1000 \mathrm{~mW}$. A pulsed solid state laser NT342/3UV (pulse duration $~ 5 \mathrm{~ns}$ ) from Ekspla (tunable wavelength from $210 \mathrm{~nm}$ to $2300 \mathrm{~nm}$, linewidth is $4.3 \mathrm{~cm}^{-1}$ ) was used for luminescence kinetics measurements. Luminescence spectra were recorded by an ICCD camera (Andor iSTAR DH734_18 mm) coupled to Andor SR-303i-B monochromator/spectrometer. Luminescence decay kinetics were ob-tained as a series of delayed luminescence spectra recorded after the excitation laser pulse (Exposure time: $0.045 \mathrm{~s}$, gate delay: $50 \mathrm{~ns}$, spec-tral range: $500-700 \mathrm{~nm}$ ).

\section{Results and discussions}

\subsection{Structural and microstuctural properties}

In Fig. 1 are given X-ray diffraction patterns of all the samples to-gether with ICDD card No. 01-086-0996 data indicating the presence of a single tetragonal zircon-type phase of $\mathrm{GdVO}_{4}$ (space group I41/amd). In the zircontype crystal lattice, $\mathrm{Gd}^{3+}$ ions (with $\mathrm{D}_{2 \mathrm{~d}}$ point symmetry) 
Table 1

Lattice parameters and average crystallite size for all synthesized $\mathrm{GdVO}_{4}: \mathrm{xmol} \mathrm{Er}^{3+} / 1$ mol $\% \mathrm{Nd}^{3+}$ and $\mathrm{GdVO}_{4}: \mathrm{xmol}^{2} \mathrm{Ho}^{3+} / 1 \mathrm{~mol}^{3 \mathrm{Nd}^{3+}}(\mathrm{x}=0.5$ or 1$)$ samples.

\begin{tabular}{|c|c|c|c|c|}
\hline $\begin{array}{l}\text { Samples (GdVO4:1 mol\% } \\
\left.\mathrm{Nd}^{3+} /\right)\end{array}$ & $\begin{array}{l}0.5 \mathrm{~mol} \% \\
\mathrm{Er}^{3+}\end{array}$ & $\begin{array}{l}1 \mathrm{~mol} \% \\
\mathrm{Er}^{3+}\end{array}$ & $\begin{array}{l}0.5 \mathrm{~mol} \% \\
\mathrm{Ho}^{3+}\end{array}$ & $\begin{array}{l}1 \mathrm{~mol} \% \\
\mathrm{Ho}^{3+}\end{array}$ \\
\hline $\mathrm{a}=\mathrm{b}(\hat{\mathrm{A}})$ & 7.21201 & 7.2114 & 7.2135 & 7.2133 \\
\hline$c(\hat{A})$ & 6.34819 & 6.3479 & 6.3497 & 6.3501 \\
\hline Crystallite size (nm) & 47.7 & 63.9 & 57.8 & 61.3 \\
\hline
\end{tabular}

are located within a distorted dodecahedron of eight $\mathrm{O}^{2-}$ ions, while $\mathrm{V}^{5+}$ ions in the $\left[\mathrm{VO}_{4}\right]^{3-}$ groups are tetrahedrally coordinated with $\mathrm{O}^{2-}$ ions. The absence of impurity phases and very small shift of reflections compared to the reflection positions of pure $\mathrm{GdVO}_{4}$ indicate that $\mathrm{Er}^{3+}\left(\mathrm{Ho}^{3+}\right)$ and $\mathrm{Nd}^{3+}$ ions were successfully and uniformly incorporated into the $\mathrm{GdVO}_{4}$ host lattice at substitutional sites due to similar ionic radii and ionic charges of the dopant and $\mathrm{Gd}^{3+}$ ions. Relatively intense reflection peaks were observed suggesting that the samples (calcined at $1150{ }^{\circ} \mathrm{C}$ for $90 \mathrm{~min}$ ) were highly crystalline and that no further thermal treatment was required. The diffraction patterns clearly shows a strong (2 00 ) preferred orientation in all the samples.

All structural parameters (average crystal size, unit cell parameters and strain) of the $\mathrm{Er}^{3+} / \mathrm{Nd}^{3+}$ - and $\mathrm{Ho}^{3+} / \mathrm{Nd}^{3+}$-doped $\mathrm{GdVO}_{4}$ were estimated by the Halder-Wagner method and by structural Rietveld refinement (see Table 1). Calculated values of crystallite size are in range from 48 to $64 \mathrm{~nm}$, while microstrain values (which are not listed in Table 1), are from 0.03 to $0.11 \%$ suggesting a good ions ordering in the nanocrystals.

Fig. 2 shows SEM images of the microstructure of the doped $\mathrm{GdVO}_{4}$ samples at different magnifications. The materials were comprised of chunks of irregular spherical (deformed) particles with an average diameter ranging from approximately $2 \mu \mathrm{m}-6 \mu \mathrm{m}$. Note that difference in doping concentrations of $\mathrm{Er}^{3+}$ or $\mathrm{Ho}^{3+}$ exhibited no effect on the morphology and crystal structure of $\mathrm{GdVO}_{4}$.

\subsection{Optical properties}

\subsubsection{Diffuse reflection spectra}

UV-Vis-NIR diffuse reflection spectra at room temperature of the $\mathrm{Er}^{3+} / \mathrm{Nd}^{3+}$ - and $\mathrm{Ho}^{3+} / \mathrm{Nd}^{3+}$-doped $\mathrm{GdVO}_{4}$ powders are given in Fig. 3. In order to facilitate their analysis, diffuse reflection spectrum of the $\mathrm{GdVO}_{4}: \mathrm{Nd}^{3+}$ powder was also recorded and presented. Wave-lengths of the band positions (marked with numbers and letters in the spectra) along with corresponding transitions are listed in Table 2.

All analyzed materials showed strong absorption in the UV spectral region. As is well-known, the strong UV absorption of vanadate mate-rials may be attributed a $\mathrm{V}^{5+}-\mathrm{O}^{2-}$ charge transfer from the excited oxygen ligands $\left(\mathrm{O}^{2-}\right)$ to the central vanadium atom $\left(\mathrm{V}^{5+}\right)$ in the $\mathrm{VO}_{4}{ }^{3-}$ groups. According to the molecular orbital theory, this corresponds to transitions from the ${ }^{1} \mathrm{~A}_{2}\left({ }^{1} \mathrm{~T}_{1}\right)$ ground state to the ${ }^{1} \mathrm{~A}_{1}\left({ }^{1} \mathrm{E}\right)$ and ${ }^{1} \mathrm{E}\left({ }^{1} \mathrm{~T}_{2}\right)$ excited states of the $\mathrm{VO}_{4}{ }^{3-}$ ions, i.e., in crystalline $\mathrm{GdVO}_{4}$, the original $\mathrm{T}_{\mathrm{d}}$ symmetry of $\mathrm{VO}_{4}{ }^{3-}$ (free ion) is reduced to $\mathrm{D}_{2 \mathrm{~d}}$ by the crystal field; this causes a splitting of the degenerate levels of $\mathrm{VO}_{4}{ }^{3-}$ [7].

Sharp narrow absorption bands of the $\mathrm{GdVO}_{4}: \mathrm{Nd}^{3+}$ sample were observed in the range from $\sim 450 \mathrm{~nm}$ to $\sim 900 \mathrm{~nm}$, and, apart from these bands, additional absorption bands appeared in the spectra of GdVO4: $\mathrm{Er}^{3+} / \mathrm{Nd}^{3+}$ and $\mathrm{GdVO}_{4}: \mathrm{Ho}^{3+} / \mathrm{Nd}^{3+}$ powders. The absorption bands (see Fig. 3 and Table 2) of $\mathrm{Nd}^{3+}, \mathrm{Er}^{3+}$ and $\mathrm{Ho}^{3+}$ could be at -

tributed to the intra-configurational f-f electronic transitions from the ground levels ${ }^{4} \mathrm{I}_{9 / 2},{ }^{4} \mathrm{I}_{15 / 2}$ and ${ }^{5} \mathrm{I}_{8}$ respectively to various excited states [21-23]. Electric dipole transitions between $4 \mathrm{f}$ levels, involving no change in parity, only occur because of interaction with the crystal field of host lattice causes mixing of electronic states. Magnetic dipole transitions between $4 \mathrm{f}$ levels are allowed, but, usually, their intensity is weak. For our purposes it is important that absorption at $808 \mathrm{~nm}$, which results from $\mathrm{Nd}^{3+}:{ }^{4} \mathrm{I}_{9 / 2} \rightarrow{ }^{4} \mathrm{~F}_{5 / 2},{ }^{2} \mathrm{H}_{9 / 2}$, was present in all the spectra.

$\mathrm{GdVO}_{4}$ is a direct band gap material with band gap energy $\mathrm{E}_{\mathrm{g}}=3.57 \mathrm{eV}$ [24]. To estimate the band gap energy of $\mathrm{GdVO}_{4}: \mathrm{Er}^{3+} / \mathrm{Nd}^{3+}$ and GdVO $4: \mathrm{Ho}^{3+} / \mathrm{Nd}^{3+}$ from the diffuse reflection spectra, the Kubelka-Munk theory was used [7,24]. The band gap $\mathrm{Eg}_{\mathrm{g}}$ value was determined by extrapolating the steepest portion of the graph on the
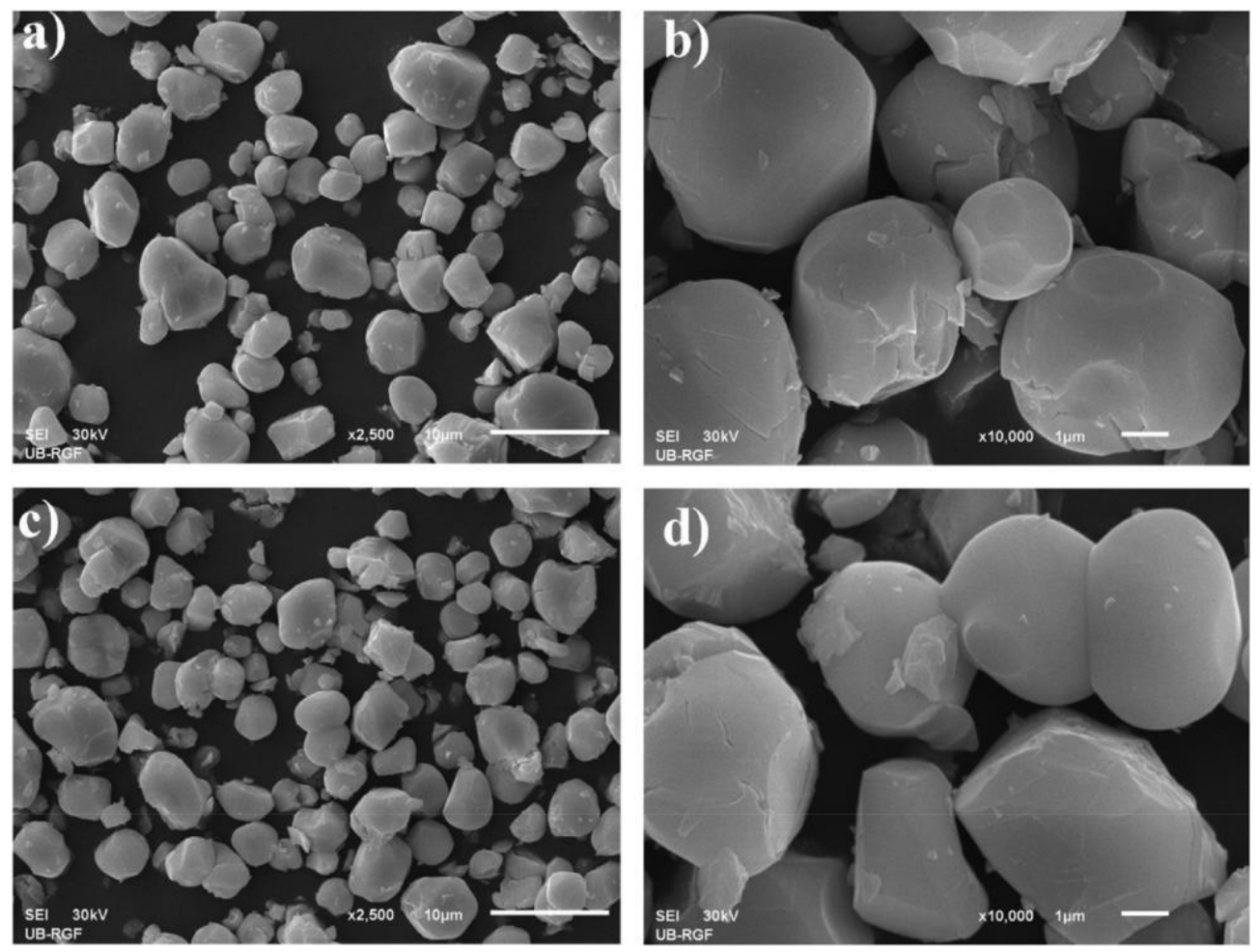

Fig. 2. SEM images of: (a, b) $\mathrm{Er}^{3+} / \mathrm{Nd}^{3+}$ - and (c, d) $\mathrm{Ho}^{3+} / \mathrm{Nd}^{3+}-$ doped $\mathrm{GdVO}_{4}$ samples at different magnifications. 

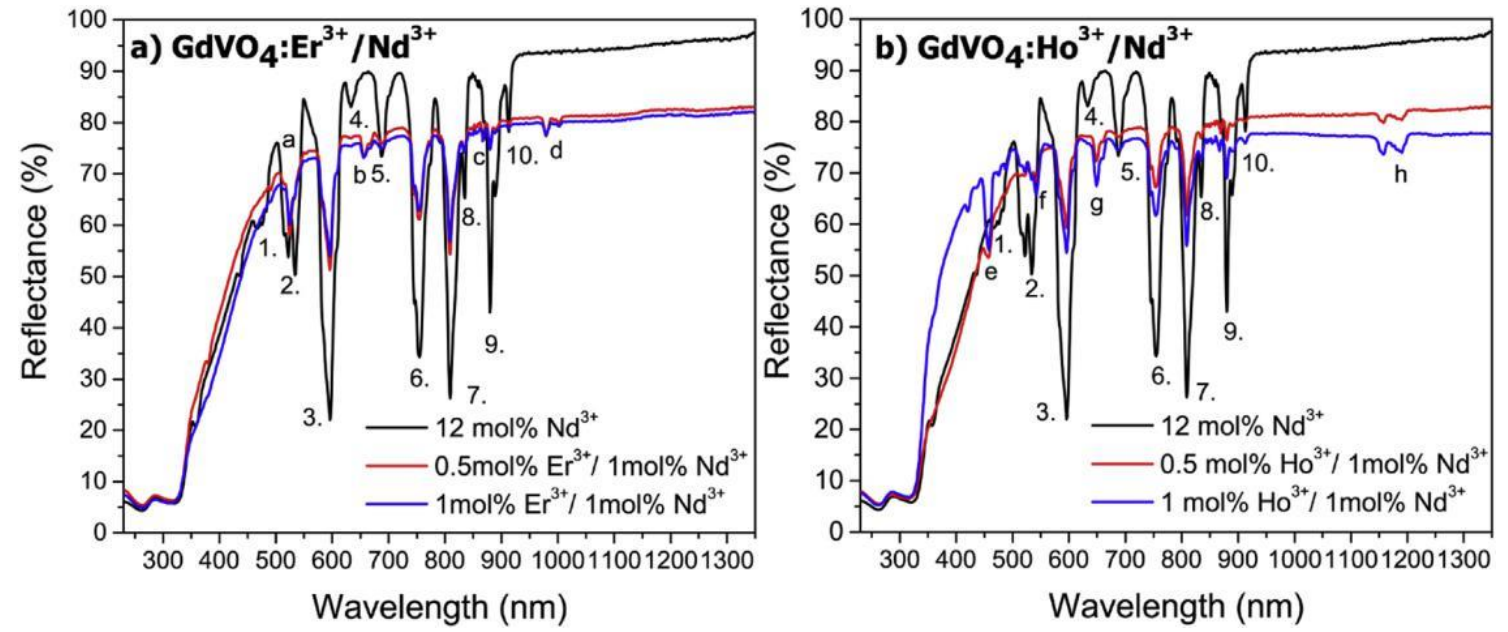

Fig. 3. Diffuse reflection spectra of: a) $\mathrm{Er}^{3+} / \mathrm{Nd}^{3+}$ - and b) $\mathrm{Ho}^{3+} / \mathrm{Nd}^{3+}$-doped $\mathrm{GdVO}_{4}$ samples. For the sake of comparison, spectra of $\mathrm{Nd}^{3+}$-doped $\mathrm{GdVO}_{4}$ are depicted in black.

Table 2

Absorption band positions and corresponding transitions from diffuse reflection spectra of $\mathrm{Nd}^{3+}-\mathrm{Er}^{3+} / \mathrm{Nd}^{3+}$ - and $\mathrm{Ho}^{3+} / \mathrm{Nd}^{3+}$-doped $\mathrm{GdVO}_{4}$ samples.

\begin{tabular}{|c|c|c|c|}
\hline Ion & Band & Wavelength (nm) & Transition \\
\hline \multirow[t]{10}{*}{$\mathrm{Nd}^{3+}$} & 1. & 468 & ${ }^{4} \mathrm{I} / / 2 \rightarrow{ }^{4} \mathrm{G} 9 / 2$ \\
\hline & 2. & $521 / 535$ & ${ }^{4} \mathrm{I} 9 / 2 \rightarrow{ }^{4} \mathrm{G}_{7 / 2},{ }^{4} \mathrm{G} 9 / 2$ \\
\hline & 3. & 596 & ${ }^{4} \mathrm{I} 9 / 2 \rightarrow{ }^{4} \mathrm{G}_{5} / 2,{ }^{4} \mathrm{G}_{7 / 2}$ \\
\hline & 4. & 634 & ${ }^{4} \mathrm{I}_{9 / 2} \rightarrow{ }^{2} \mathrm{H}_{11 / 2}$ \\
\hline & 5. & 685 & ${ }^{4} \mathrm{I} 9 / 2 \rightarrow{ }^{4} \mathrm{~F} 9 / 2$ \\
\hline & 6. & 753 & ${ }^{4} \mathrm{I}_{9 / 2} \rightarrow{ }^{4} \mathrm{~F}_{7 / 2},{ }^{4} \mathrm{~S}_{3 / 2}$ \\
\hline & 7. & 808 & ${ }^{4} \mathrm{I}_{9 / 2} \rightarrow{ }^{4} \mathrm{~F}_{5 / 2},{ }^{2} \mathrm{H} 9 / 2$ \\
\hline & 8. & 833 & ${ }^{4} \mathrm{I} 9 / 2 \rightarrow{ }^{4} \mathrm{~F}_{5 / 2},{ }^{2} \mathrm{H}_{9 / 2}$ \\
\hline & 9. & 881 & ${ }^{4} \mathrm{I}_{9 / 2} \rightarrow{ }^{4} \mathrm{~F}_{3 / 2}$ \\
\hline & 10. & 915 & ${ }^{4} \mathrm{I} 9 / 2 \rightarrow{ }^{4} \mathrm{~F}_{3} / 2$ \\
\hline \multirow[t]{4}{*}{$\mathrm{Er}^{3+}$} & $\mathrm{a}$ & 524 & ${ }^{4} \mathrm{I}_{15 / 2} \rightarrow{ }^{2} \mathrm{H}_{11 / 2}$ \\
\hline & $\mathrm{b}$ & 655 & ${ }^{4} \mathrm{I}_{15 / 2} \rightarrow{ }^{4} \mathrm{~F} 9 / 2$ \\
\hline & $\mathrm{c}$ & 864 & ${ }^{4} \mathrm{I} 15 / 2 \rightarrow{ }^{4} \mathrm{I} 9 / 2$ \\
\hline & d & $980 / 1004$ & ${ }^{4} \mathrm{I} 15 / 2 \rightarrow{ }^{4} \mathrm{I} 11 / 2$ \\
\hline \multirow[t]{4}{*}{$\mathrm{Ho}^{3+}$} & $\mathrm{e}$ & 456 & ${ }^{5} \mathrm{I} 8 \rightarrow{ }^{5} \mathrm{G} 6$ \\
\hline & $f$ & 544 & ${ }^{5} \mathrm{I} 8 \rightarrow{ }^{5} \mathrm{~S}_{2},{ }^{5} \mathrm{~F} 4$ \\
\hline & $\mathrm{g}$ & 647 & ${ }^{5} \mathrm{I} 8 \rightarrow{ }^{5} \mathrm{~F} 5$ \\
\hline & $\mathrm{h}$ & $1152 / 1191$ & ${ }^{5} \mathrm{I}_{8} \rightarrow{ }^{5} \mathrm{I} 6$ \\
\hline
\end{tabular}

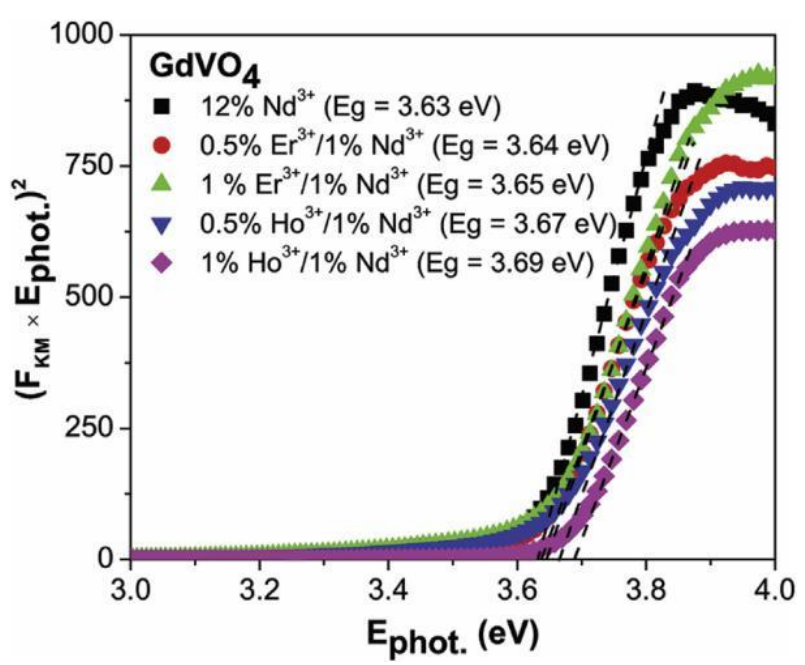

Fig. 4. Band gap energy values, $E_{g}(e V)$, calculated from diffuse reflection spectra. All the studied samples together with $\mathrm{GdVO}_{4}: 12 \% \mathrm{Nd}^{3+}$ are considered.
$E_{\text {phot }}$ axis at $\left(F_{K M} \times E_{\text {phot. }}\right)^{2}=0$ as it is shown in Fig. 4. The estimated band gap values in the range from $3.63 \mathrm{eV}$ up to $3.69 \mathrm{eV}$ are in full agreement with recently published results for $\mathrm{GdVO}_{4}$. Note a small blue-shift for the absorption edge of double-doped $\mathrm{GdVO}_{4}$ due to in-fluence of doping (see Fig. $4)$.

\subsubsection{Up-conversion luminescence under $808 \mathrm{~nm}$ excitation}

Fig. 5 shows visible luminescence emission under $808 \mathrm{~nm}$ excitation of GdVO4: $\mathrm{Nd}^{3+} / \mathrm{Er}^{3+}$ and $\mathrm{GdVO}_{4}: \mathrm{Nd}^{3+} / \mathrm{Ho}^{3+}$ recorded at room tem-perature. For all the samples, three or four bands in luminescence spectra were observed, each containing multiple peaks.

In case of $\mathrm{GdVO}_{4}: \mathrm{Nd}^{3+} / \mathrm{Er}^{3+}$, luminescence emission was found in the ranges $520-565 \mathrm{~nm}, 570-630 \mathrm{~nm}$ and $640-680 \mathrm{~nm}$. Spectra of dif-ferent samples are similar in shape, there is no shift in the peak posi-tions but there is a change in the intensity of the peaks. The observed green and red emissions around $525 \mathrm{~nm}, 550 \mathrm{~nm}$ and $675 \mathrm{~nm}$ are con-sistent with the wellknown electronic transitions to the ground state level ${ }^{4} \mathrm{I}_{15 / 2}$ from higher levels in $\mathrm{Er}^{3+}$ ions: ${ }^{2} \mathrm{H}_{11 / 2} \rightarrow{ }^{4} \mathrm{I}_{15 / 2},{ }^{4} \mathrm{~S}_{3 / 2} \rightarrow{ }^{4} \mathrm{I}_{15 /}$

2 and ${ }^{4} \mathrm{~F}_{9 / 2} \rightarrow{ }^{4} \mathrm{I}_{15 / 2}$, respectively [21,23]. The luminescence centred on $597 \mathrm{~nm}$ should be attributed to the transition ${ }^{4} \mathrm{G} 7 / 2 \rightarrow{ }^{4} \mathrm{I}_{11 / 2}$ in $\mathrm{Nd}^{3+}$ ions $[23,24]$. In case of $\mathrm{GdVO}_{4}: \mathrm{Nd}^{3+} / \mathrm{Ho}^{3+}$, three luminescence bands were observed. Again, spectra of different samples are similar in shape with no apparent change in the peak positions, but they differ in lu-minescent intensity. The dominant 597-nm emission is characteristic of the ${ }^{4} \mathrm{G}_{7 / 2} \rightarrow$ ${ }^{4} \mathrm{I}_{11 / 2}$ transition in $\mathrm{Nd}^{3+}$ ions [23,24], while other bands could be due to electronic transitions to the ground state level ${ }^{5} \mathrm{I}_{8}$ from higher levels in $\mathrm{Ho}^{3+}$ ions: ${ }^{5} \mathrm{~F}_{4},{ }^{5} \mathrm{~S}_{2} \rightarrow{ }^{5} \mathrm{I}_{8}(540 \mathrm{~nm})$ and ${ }^{5} \mathrm{~F}_{5} \rightarrow{ }^{5} \mathrm{I}_{8}(659 \mathrm{~nm})[22,26]$.

Clearly, 808-nm excited upconversion was achieved in all the doubledoped $\mathrm{GdVO}_{4}$ samples, however, the determination of the governing mechanism behind luminescence is not at all straightfor-ward. In general, changing the host materials (differing the phonon energy) may substantially influence the multi-phonon relaxation as well as energy transfer process, which may lead to an entirely different up-conversion luminescence behavior. It is well-known that around

$800 \mathrm{~nm}$, absorption cross section of $\mathrm{Nd}^{3+}$ is relatively high, while commonly used activators $\left(\mathrm{Er}^{3+}, \mathrm{Tm}^{3+}\right.$, and $\left.\mathrm{Ho}^{3+}\right)$ and sensitizer $\left(\mathrm{Yb}^{3+}\right)$ exhibit extremely low-absorption cross section. Also, it is known that $\mathrm{Nd}^{3+}$ can produce UC luminescence in single-doped $808 \mathrm{~nm}$-ex-cited materials [25,27]. However, it was reported that $\mathrm{Er}^{3+}$ and $\mathrm{Ho}^{3+}$ ions also show visible UC luminescence under 808 excitation in certain single-doped host lattices $[28,29]$. Here, the presence of emission lines from erbium/holmium and neodymium ions in the luminescence spectra of $\mathrm{Nd}^{3+} / \mathrm{Er}^{3+}$-doped $\mathrm{GdVO}_{4}$ and $\mathrm{Nd}^{3+} / \mathrm{Ho}^{3+}$-doped $\mathrm{GdVO}_{4}$ indicates a multistage energy transfer between active centers. The $\mathrm{Nd}^{3+}$ 

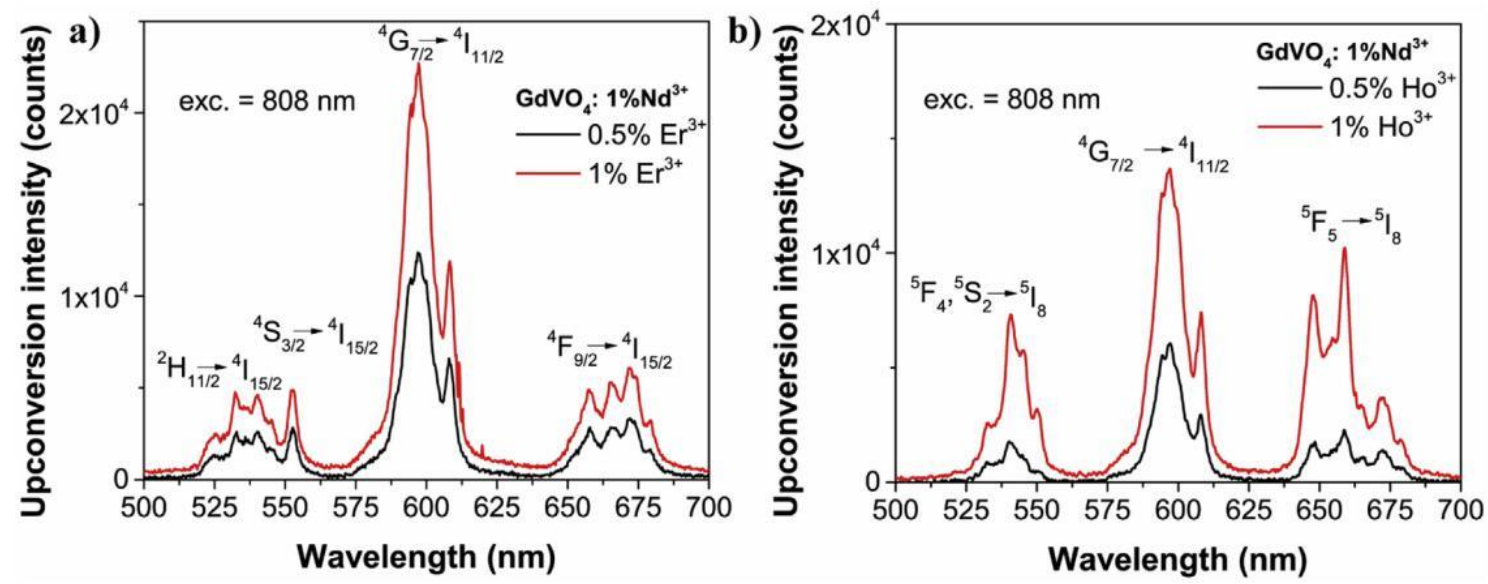

Fig. 5. Visible UC luminescence emission spectra of: a) $\mathrm{Er}^{3+} / \mathrm{Nd}^{3+}$ - and b) $\mathrm{Ho}^{3+} / \mathrm{Nd}^{3+}$-doped $\mathrm{GdVO}_{4}$ samples.

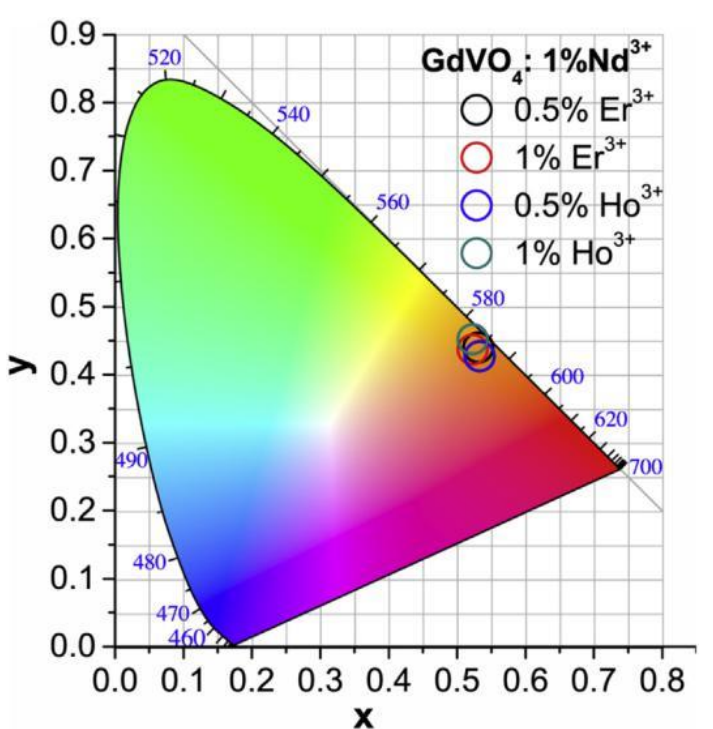

Fig. 6. CIE coordinates of the UC luminescence color for all the studied phos-phors. (For interpretation of the references to color in this figure legend, the reader is referred to the Web version of this article.)

emission at about $597 \mathrm{~nm}$, which dominated in all the spectra, is par-ticularly interesting and an increase of its intensity with increasing of the number of $\mathrm{Er}^{3+} / \mathrm{Ho}^{3+}$ ions could be associated with efficient $\mathrm{Er}^{3+} / \mathrm{Ho}^{3+}-\mathrm{Nd}^{3+}$ energy transfer. The above results definitely confirmed UC luminescence $\left(\lambda_{\mathrm{exc}}=808\right.$ $\mathrm{nm}$ ), but possible mechanisms of the energy transfer processes between ions and how our findings can be inter-preted certainly requires further investigation.

An average lifetime for all samples and all emission maxima were estimated using the following equation: $\tau_{\text {avg. }}=\int_{t} t(t) d t / \int_{0}^{\infty} I(t) d t$,

where $I(t)$ represents the luminescence intensity at time $t$ corrected for the background; the integrals were evaluated in the range $0<\mathrm{t}<\mathrm{t}_{\mathrm{m}}$ where $\mathrm{t}_{\mathrm{m}} \ll$ Tavg [30]. Calculated average lifetime values for all the samples under excitation at $808 \mathrm{~nm}$ were in the range from 13 up to $35 \mu$ s for the samples $\mathrm{GdVO}_{4}: 1 \mathrm{~mol} \% \mathrm{Nd}^{3+} / 1 \mathrm{~mol}^{2} \mathrm{Ho}^{3+}$ and GdVO $4: 1 \mathrm{~mol} \% \mathrm{Nd}^{3+} / 0.5 \mathrm{~mol} \% \mathrm{Er}^{3+}$, respectively.

For visualization of the color of emitted light from the samples the color coordinates were determined and are shown in the CIE chroma-ticity diagram in Fig. 6. The calculated color coordinates $(x, y)$ for in-vestigated materials were calculated to be as follows: $(0.531,0.440) \mathrm{GdVO}_{4}: 1 \% \mathrm{Nd}^{3+} / 0.5 \% \mathrm{Er}^{3+}$, $\left.\begin{array}{lllll}(0.523, & 0.437) & \mathrm{GdVO}_{4}: 1 \% \mathrm{Nd}^{3+} / 1 \% \mathrm{Er}^{3+}, & (0.533, & 0.427\end{array}\right)$ GdVO $4: 1 \% \mathrm{Nd}^{3+} / 0.5 \% \mathrm{Ho}^{3+}$ and $(0.523,0.452)$
GdVO4: $1 \% \mathrm{Nd}^{3+} / 1 \% \mathrm{Ho}^{3+}$.

\section{Conclusions}

It could be concluded from the literature that $\mathrm{Yb}^{3+}$-sensitized $\mathrm{GdVO}_{4}$ based materials, including $\mathrm{GdVO}_{4}: \mathrm{Yb}^{3+} / \mathrm{Er}^{3+}, \mathrm{GdVO}_{4}: \mathrm{Yb}^{3+} / \mathrm{Ho}^{3+}$ and GdVO $4: \mathrm{Yb}^{3+} / \mathrm{Tm}^{3+}$, are rather well studied. These powders with particles of sizes ranging from several nanometers to several mi-crometers have been prepared by verious synthetic techniques and they exhibit UC luminescence emission under excitation at $980 \mathrm{~nm}$. However, it appears that optical properties of double-doped $\mathrm{GdVO}_{4}$ systems under $808 \mathrm{~nm}$ excitation were not studied at all before.

Double-doped GdVO4-based polycrystalline powders, GdVO4:xmol $\% \mathrm{Ho}^{3+} / 1 \mathrm{~mol} \% \mathrm{Nd}^{3+}$ and $\mathrm{GdVO}_{4}: \mathrm{xmol}^{2} \mathrm{Er}^{3+} / 1 \mathrm{~mol} \% \mathrm{Nd}^{3+}(\mathrm{x}=0.5$ and 1$)$, were successfully prepared by a high-temperature solid-state reaction technique. The obtained materials consisting of micrometer-sized irregular spherical particles $(2-6 \mu \mathrm{m}$ in diameter) were highly crystalline and a single tetragonal zircon-type phase of $\mathrm{GdVO}_{4}$ (space group I41/amd) was confirmed in all samples.

By making use of an inexpensive laser diode $(1 \mathrm{~W})$ as an excitation source, UC luminescence emission (recorded in the 500-715 $\mathrm{nm}$ range) was successfully achieved in all the samples under $808 \mathrm{~nm}$ illumination. NIR pumping produced emission bands in the green, yellow-orange and red regions of the visible spectrum. In all studied materials, the domi-nant band originating from the ${ }^{4} \mathrm{G}_{7 / 2} \rightarrow{ }^{4} \mathrm{I}_{11 / 2}$ transition in $\mathrm{Nd}^{3+}$ ions was observed around $597 \mathrm{~nm}$. The bands in the green and red regions of $\mathrm{GdVO}_{4}$ : $\mathrm{Er}^{3+} / \mathrm{Nd}^{3+}$ as well as $\mathrm{GdVO}_{4}: \mathrm{Ho}^{3+} / \mathrm{Nd}^{3+}$ were, respectively, characteristic of $\mathrm{Er}^{3+}$ and $\mathrm{Ho}^{3+}$ ions. These initial results of an ongoing research certainly require further investigation.

\section{Acknowledgements}

All authors acknowledge to the COST Action CM1403: The European upconversion network - from the design of photon-upcon-verting nanomaterials to biomedical applications (2014-2018). The authors from the University of Belgrade acknowledge the financial support of the Ministry of Education, Science and Technological Development of the Republic of Serbia (Project Nos. 45020 and 172056). K. S. acknowledges the Latvian National Research Program IMIS2 (Grant No. 302/2012). T. G. acknowledges the ERDF PostDoc project No. 1.1.1.2/VIAA/1/16/215 (1.1.1.2/16/I/001).

\section{References}

[1] J. Zhou, Q. Liu, W. Feng, Y. Sun, F. Li, Upconversion luminescent materials: advances and applications, Chem. Rev. 115 (2015) 395-465.

[2] S. Wang, H. Zhang, Chapter 7, foundations of up-conversion nanoparticles, in: R.- 
S. Liu (Ed.), Phosphors, up Conversion Nano Particles, Quantum Dots and Their Applications, vol. 2, Springer, 2016.

[3] G.-R. Tan, M. Wang, C.-Y. Hsu, N. Chen, Y. Zhang, Small upconverting fluorescent nanoparticles for biosensing and bioimaging, Adv. Opt. Mater. 4 (2016) 984-997.

[4] M.K.G. Jayakumar, N.M. Idris, K. Huang, Y. Zhang, A paradigm shift in the ex-citation wavelength of upconversion nanoparticles, Nanoscale 6 (2014) 8441-8143.

[5] Y.-F. Wang, G.-Y. Liu, L.-D. Sun, J.-W. Xiao, J.-C. Zhou, C.-H. Yan, $\mathrm{Nd}^{3+}$-sensitized upconversion nanophosphors: efficient in vivo bioimaging probes with minimized heating effect, ACS Nano 7 (2013) 7200-7206.

[6] X. Xie, Z. Li, Y. Zhang, S. Guo, A.I. Pendharkar, M. Lu, L. Huang, W. Huang, G. Han, Emerging $\approx 800 \mathrm{~nm}$ excited lanthanide-doped upconversion nanoparticles, Small 13 (2017) 1602843 (15 pp).

[7] T.V. Gavrilović, D.J. Jovanović, V. Lojpur, M.D. Dramićanin, Multifunctional $\mathrm{Eu}^{3+}$ and $\mathrm{Er}^{3+} / \mathrm{Yb}^{3+}$-doped $\mathrm{GdVO}_{4}$ nanoparticles synthesized by reverse micelle method, Sci. Rep. 4 (2014) 4209.

[8] T.V. Gavrilović, D.J. Jovanović, K. Smits, M.D. Dramićanin, Multicolor upconver-sion luminescence of GdVO4: $\mathrm{Ln}^{3+} / \mathrm{Yb}^{3+}\left(\mathrm{Ln}^{3+}=\mathrm{Ho}^{3+}, \mathrm{Er}^{3+}, \mathrm{Tm}^{3+}, \mathrm{Ho}^{3+} / \mathrm{Er}^{3+} / \mathrm{Tm}^{3+}\right)$ nanorods, Dyes Pigments 126 (2016) 1-7.

[9] K. Dong, E. Ju, J. Liu, X. Han, J. Ren, X. Qu, Ultrasmall biomolecule-anchored hybrid GdVO 4 nanophosphors as a metabolizable multimodal bioimaging contrast agent, Nanoscale 6 (2014) 12042-12049.

[10] T.V. Gavrilović, D.J. Jovanović, L.V. Trandafilović, M.D. Dramićanin, Effects of Ho ${ }^{3+}$ and $\mathrm{Yb}^{3+}$ doping concentrations and $\mathrm{Li}^{+}$co-doping on the luminescence of $\mathrm{GdVO}_{4}$ powders, Opt. Mater. 45 (2015) 76-81.

[11] Y. Liang, H.M. Noh, J. Xue, H. Choi, S.H. Park, B.C. Choi, J.H. Kim, J.H. Jeong, High quality colloidal GdVO4: $\mathrm{Yb}$,Er upconversion nanoparticles synthesized via a pro-tected calcination process for versatile applications, Mater. Des. 130 (2017) 190-196.

[12] A. Tymiński, T. Grzyb, S. Lis, REVO4 -based nanomaterials ( $\mathrm{RE}=\mathrm{Y}, \mathrm{La}, \mathrm{Gd}$, and Lu) as hosts for $\mathrm{Yb}^{3+} / \mathrm{Ho}^{3+}, \mathrm{Yb}^{3+} / \mathrm{Er}^{3+}$ and $\mathrm{Yb}^{3+} / \mathrm{Tm}^{3+}$ ions: structural and up-con-version luminescence studies, J. Am. Ceram. Soc. 99 (2016) 3300-3308.

[13] O.A. Savchuk, J.J. Carvajal, C. Cascales, M. Aguiló, F. Díaz, Benefits of silica coreshell structures on the temperature sensing properties of Er, $\mathrm{Yb}: \mathrm{GdVO}_{4}$ up-conversion nanoparticles, ACS Appl. Mater. Interfaces 8 (2016) 7266-7273.

[14] J.H. Oh, B.K. Moon, B.C. Choi, J.H. Jeong, J.H. Kim, H.S. Lee, The green upconversion emission mechanism investigation of $\mathrm{GdVO} 4: \mathrm{Yb}^{3+}, \mathrm{Er}^{3+}$ via tuning of the sensitizer concentration, Solid State Sci. 42 (2015) 1-5

[15] T.V. Gavrilović, D.J. Jovanović, V.M. Lojpur, V. Đorđević, M.D. Dramićanin, Enhancement of luminescence emission from $\mathrm{GdVO}_{4}: \mathrm{Er}^{3+} / \mathrm{Yb}^{3+}$ phosphor by $\mathrm{Li}^{+}$codoping, J. Solid State Chem. 217 (2014) 92-98.

[16] X. Kang, D. Yang, Y. Dai, M. Shang, Z. Cheng, X. Zhang, H. Lian, P. Ma, J. Lin, Poly (acrylic acid) modified lanthanide-doped $\mathrm{GdVO}_{4}$ hollow spheres for up-conversion cell imaging, MRI and pH-dependent drug release, Nanoscale 5 (2013) 253-261.

[17] V. Mahalingam, C. Hazra, R. Naccache, F. Vetrone, J.A. Capobianco, Enhancing the color purity of the green upconversion emission from $\mathrm{Er}^{3+} / \mathrm{Yb}^{3+}$-doped $\mathrm{GdVO}_{4}$ nanocrystals via tuning of the sensitizer concentration, J. Mater. Chem. C 1 (2013) 65366540.

[18] W. Yin, L. Zhou, Z. Gu, G. Tian, S. Jin, L. Yan, X. Liu, G. Xing, W. Ren, F. Liu, Z. Pan, Y. Zhao, Lanthanide-doped $\mathrm{GdVO}_{4}$ upconversion nanophosphors with tunable emissions and their applications for biomedical imaging, J. Mater. Chem. 22 (2012) 6974-6981.

[19] R. Calderon-Villajos, C. Zaldo, C. Cascales, Enhanced upconversion multicolor and white light luminescence in $\mathrm{SiO}_{2}$-coated lanthanide-doped $\mathrm{GdVO}_{4}$ hydrothermal nanocrystals, Nanotechnology 23 (2012) 505205 (10pp).

[20] H.K. Yang, S.J. Park, J.Y. Park, J.-Y. Je, Influence of the variation $\mathrm{Yb}^{3+}$ con-centration and sintering temperature in $\mathrm{GdVO}_{4}: \mathrm{Tm}^{3+} / \mathrm{Yb}^{3+}$ blue emission phos-phors, Optik 131 (2017) 475-482.

[21] P. Wang, H. Xia, J. Peng, H. Hu, L. Tang, Y. Zhang, B. Chen, H. Jiang, Concentration effect of $\mathrm{Nd}^{3+}$ ion on the spectroscopic properties of $\mathrm{Er}^{3+} / \mathrm{Nd}^{3+}$ co-doped LiYF4 single crystal, Mater. Chem. Phys. 144 (2014) 349-354.

[22] J. Qiuy, M. Shojiyay, R. Kannoy, Y. Kawamotoy, M. Takahashi, Selectively strong green up-conversion luminescence in co-doped -based fluoride glasses under $800 \mathrm{~nm}$ excitation, J. Phys. Condens. Matter 10 (1998) 11095-11102.

[23] Y. Xu, J. Qi, J. Ren, G. Chen, F. Huang, Y. Li, S. Lu, S. Dai, Luminescence and energy transfer in $\mathrm{Er}^{3+} / \mathrm{Nd}^{3+}$ ion-codoped Ge-In-S-CsBr chalcohalide glasses, Mater. Res. Bull. 48 (2013) 4733-4737.

[24] P. Kumari, J. Manam, Structural, optical and special spectral changes of Dy ${ }^{3+}$ emissions in orthovanadates, RSC Adv. 5 (2015) 107575.

[25] X.D. Li, X. Yu, J. Gao, F. Chen, J.H. Yu, D.Y. Chen, Upconversion spectra of $\mathrm{Nd}: G d V O 4$ crystal under CW $808 \mathrm{~nm}$ diode-laser pumping, Laser Phys. Lett. 6 (2009) $125-128$.

[26] J. Yuan, S.X. Shen, D.D. Chen, Q. Qian, M.Y. Peng, Q.Y. Zhang, Efficient $2.0 \mu \mathrm{m}$ emission in $\mathrm{Nd}^{3+} / \mathrm{Ho}^{3+}$ co-doped tungsten tellurite glasses for a diode pump $2.0 \mu \mathrm{m}$ laser, J. Appl. Phys. 113 (2013) 173507.

[27] Near-infrared-to-near-infrared down-shifting and upconversion luminescence of $\mathrm{KY}_{3} \mathrm{~F}_{10}$ with single dopant of $\mathrm{Nd}^{3+-}$ ion, Appl. Phys. Lett. 108 (2016) 041902.

[28] R. Lisiecki, W. Ryba-Romanowski, E. Cavalli, M. Bettinelli, Optical spectroscopy of $\mathrm{Er}^{3+-}$ doped LaVO4 crystal, J. Lumin. 130 (2010) 131-136.

[29] S.-Y. Liao, R. Yao, Y.-C. Liu, X.-Y. Chen, X.-Y. Hua, F. Zheng, Green up-conversion of $\mathrm{C} 12 \mathrm{~A} 7-\mathrm{Ho}^{3+}$ prepared by co-precipitation method, J. Alloy. Comp. 642 (2015) 7-14.

[30] S. Shionoya, W.M. Yen, Phosphor Handbook, CRC Press LLC, Boca Raton, 1999. 